\title{
霎について
}

横浜国大物理学教堂孫野長治

\section{§.1. 序論}

黌という言葉は使いかたのあいまいな慣用語で女つて，雨と雪とがょじつて降る状態を指寸場合（詳解漢和大辞典）

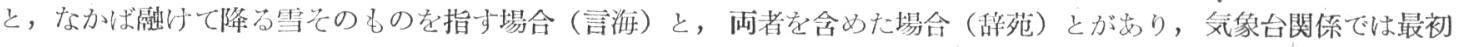
の定義と同じく，睛・雨等とならんで天候を示寸言葉として使つているようである。

ところが万国雪水協会の降雪の分類法では通常，露と訳される“Sleet"の例として碀雨（雨滴が外側から涷結した 子の）の䯈けかかつた窎真を挙げているので，一般的なはつきりした定義が出来てないようである。いずれにしても

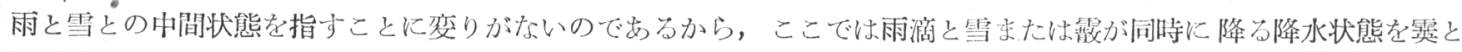

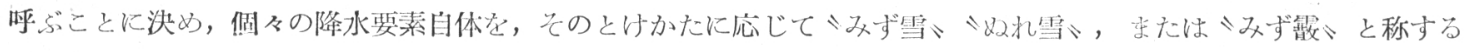
ことにする。この定義住つて，本論文では主として椟の場合の降水要素の数や谷積の度数分布の测定法について述 ベる。

従来の吸取紙に上る雨滴の観測法では質量分有だけしか記録されないので，形や比重が問題となるよ5な降水要素

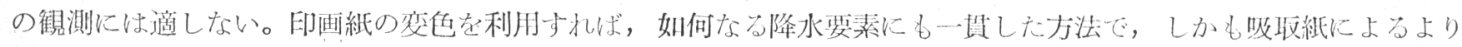
も更に簡単な操作で, 大体の形や欲積分有が記録される。

\section{§2. 印画紙の変色による降水要素つ記錄}

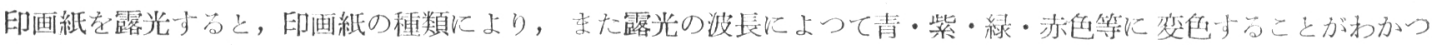

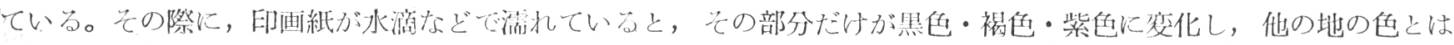
明膫に区别される。この現象を利月して降水要素を観測しよ5とするのであつて，現像・定着の操作怔一切不要であ

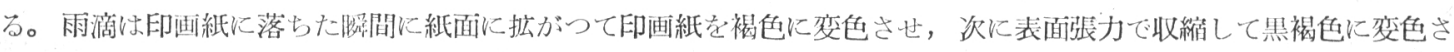
せるので，第1図に示すやうな痕跡が得られる。ここでは最 初の痕跡を雨滴の記録として採州することに決める。

印画紙は，期限切れでも，多少から゙つていても乾いて打りさ

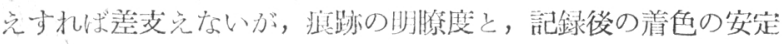
度之起考慮すれば，染井FS，八重FS，吉野No.4，日出No.2

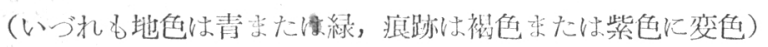
が優れて抽り，以後直射日光にさらしたり濕めらせたりしなけ れば，着色は半永久的に安定である。

露光用の光は直射日光, 明るい透明電球 (例克ば幺燈器用の 電球），水銀燈等がよく，いずれもその中の短波長の部分が利 用される。露光時間は強さにより異るか゚，1２0 分間で充分で ある。

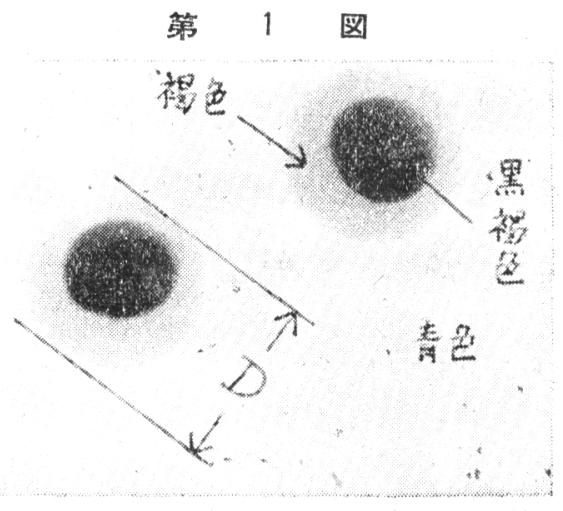




\section{$\S 3$. 雨滴の 観測 法}

\section{a) 雨滴と印画紙の痕跡}

雨滴の大ささと痕跡の大きさとの関係を, 予め検定して未ぐ必要がある。ところが，水嗬の大きさが等しくても， その落下速度によつて痕跡の大きさが槰うことがわからた。 そこで，水滴が終端速度を得るに充分な高さから水滴を印画 紙に落し，关の痕跡と水滴の直径（水滴を落与前後の印画紙 の重量増加から算出）との関係を調べた結果を第 2 図に示 す。直径 $2.3 \mathrm{~mm} \sim 7.0 \mathrm{~mm}$ の水㵜は外径の買るガラス管から 滴下させて作り，図では O印で示してある。これ以下の水 滴は滴下法では团難なので, $1.8 \mathrm{~mm}$ 以下の水襍は注射針の 先から噴出させて作つた。印。との中の $0.7 \mathrm{~mm}$ 以下の水 滴の質量は，影微鏡測定から算出した。O印。図から印画紙 上の痕跡の（第 1 図参照）直径 $\mathrm{Dmm}$ と水㘖の直径 $\mathrm{dmm}$

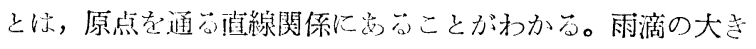
さが雾に近ずけば，疾跡の径も零に近ずく䈯で女るから，直 線が原点を通るであらうことけ予想されたことである。

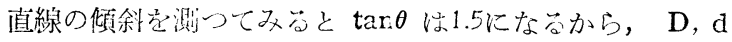
をmm単位で表すと

$$
\begin{gathered}
\log 10 D=1.5 \log 10 \mathrm{~d} \\
\mathrm{D}=10^{\mathrm{x} / 2} \mathrm{~d}^{3 / 2}
\end{gathered}
$$

の関係がある。 D が d の3/2乘に比例与ることは, 痕跡の面 積が水滴の体積に比例与うことを示

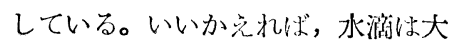
きさの吝何にかかわらず一度は凡て 厚さの一様な円盤形に拡がるること を表している。この一様な厚さは $0.067 \mathrm{~mm}$ に相当する。

この検定法に缒つて, 図版 I の雨 滴の痕跡を整理した結果を第 3 図 に示す。図は雨滴の直径の巾 $0.2 \mathrm{~mm}$ 毎の分布を表しているが，高橋喜裳 氏が指摘されたように，二つの山が 見觉る。

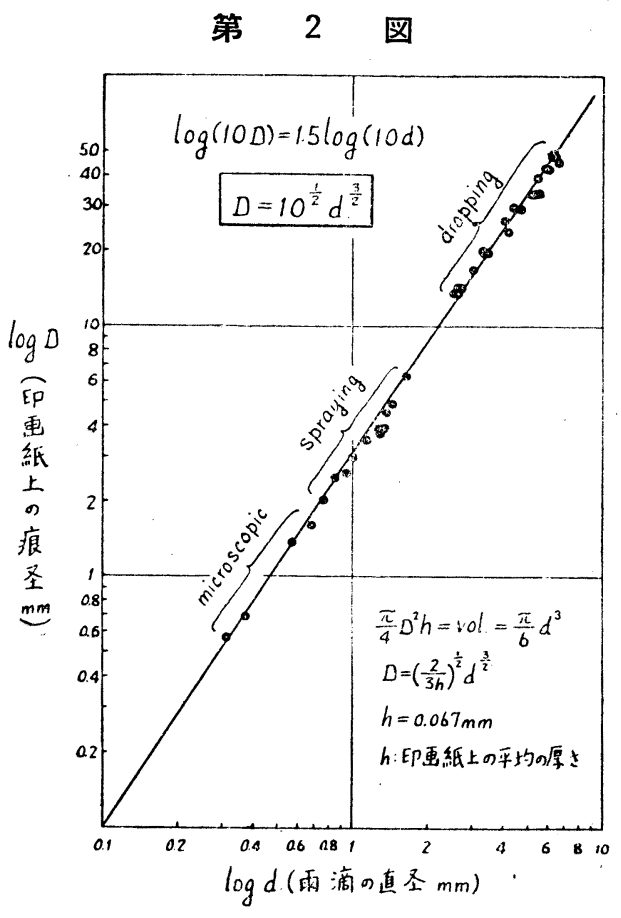

第 3 図

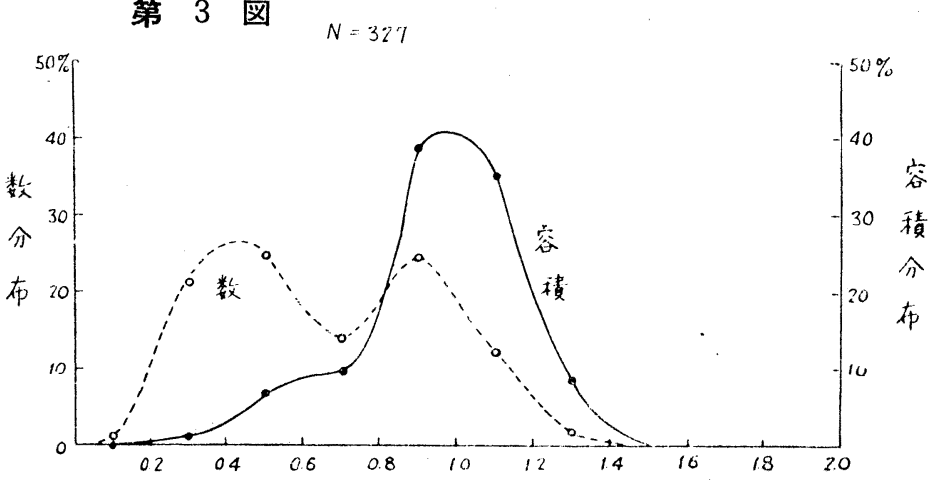

雨激の平坞直圣 $\mathrm{mm}$

\section{§ 4. 其の他の降水要素の顴測法}

a) 雪 $\quad$ 片

雪片は印紙画に落下すると上下にはいくらかつぶれはするが，横方向には拡らないから，印画紙上の痕跡が，落下 中の雪片の水平断面の形と面積とを示すものと考えてよい。従つて雪片以痕跡の最大直径（痕跡が円と見做也ない芬 合は長径と短径の幾何平均を採用）を直径とするような球と考元れば，雪片の落下中の体積が推定される。雪片を受 


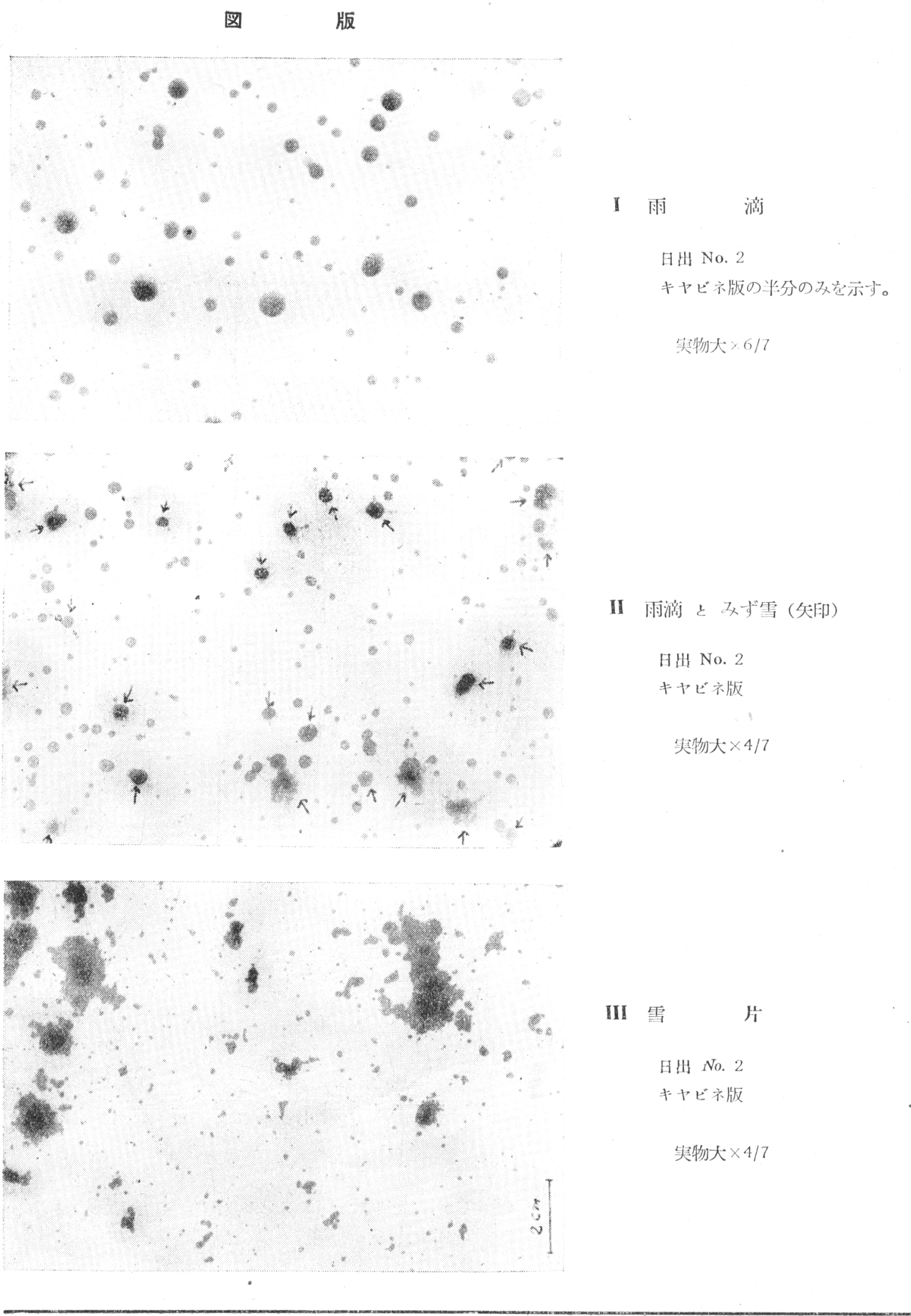




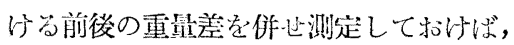
雪片の平均密度も計算され兮訳である。図

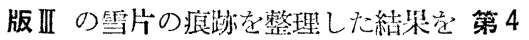
図に示与。この場合，叟片の密度は 0.016 $\mathrm{g} / \mathrm{cm}^{3}$ で非常に軽く，そのために数の頻

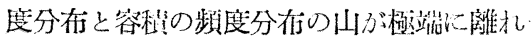
ている。容䅡分布の小さい方の山心単結 品, 又心破片の分布を示すものらしい。

時には結合が脆くて，落下の際に印画紙 上にららばる些片bむるが，この場合は雪 片の落下中の形や容䅡の推定林困難でせる が，これは吸取紙で受けても同じことでせ る。印画紙の場合は适に筜片の脆さ加减が 記録される。

\section{b)ぬれ雪・みず雪}

明かにびしよびしよに活れたた箐片は落 下すると印画悢の上で䐝方向に拡がるが， 雨滴のように後で収縮与うようなことは ない。大撜の場合，横に拡つた狆雪の 厚さは $1 \mathrm{~mm}$ 前後に一定していることが 多い。従つて，この厚さの大体老测つて 出き，厚さ一䇥で面秘觉が痕跡で示される

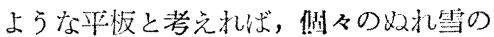
容積が推定される。この際, 印画紙の重

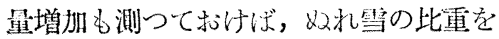
水々水の中間の 0.95 と仮定して，先に一 定と考学た厚さの補正も出来る。

みず筜といらのは，水觙中に二三の水 粒の残つた雨泀を指しているのである

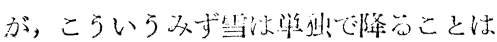

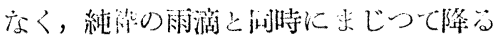
ので 85 で述べる。

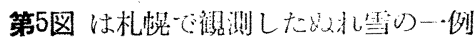

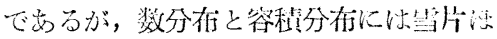
どの開きが見られない。

\section{c) 霞}

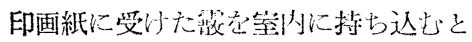
大小に抅らず半球形に融礼るから, 痕跡 $\mathrm{D}$ と水球に換算した霜の直径 $\mathrm{d}$ との間 には

$$
\mathrm{D}^{3}=2 \mathrm{~d}^{3}
$$

の関係方成立与る。第6図に観測の一 例を示す。

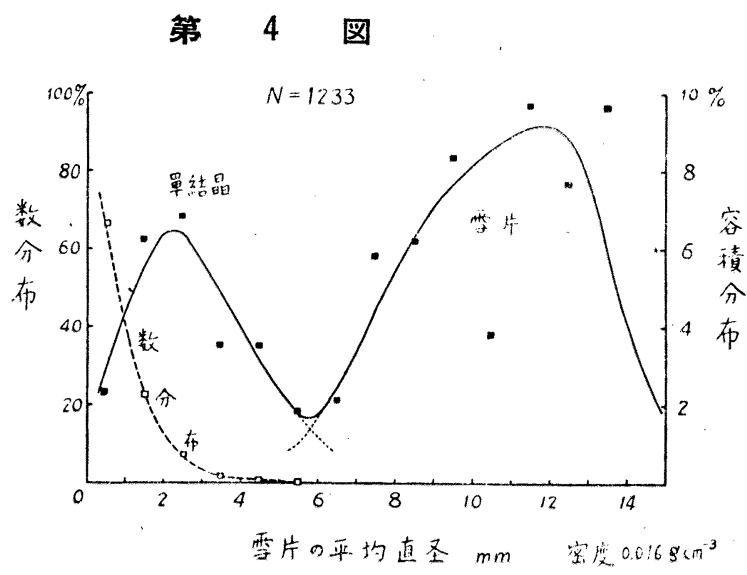

第 5 図

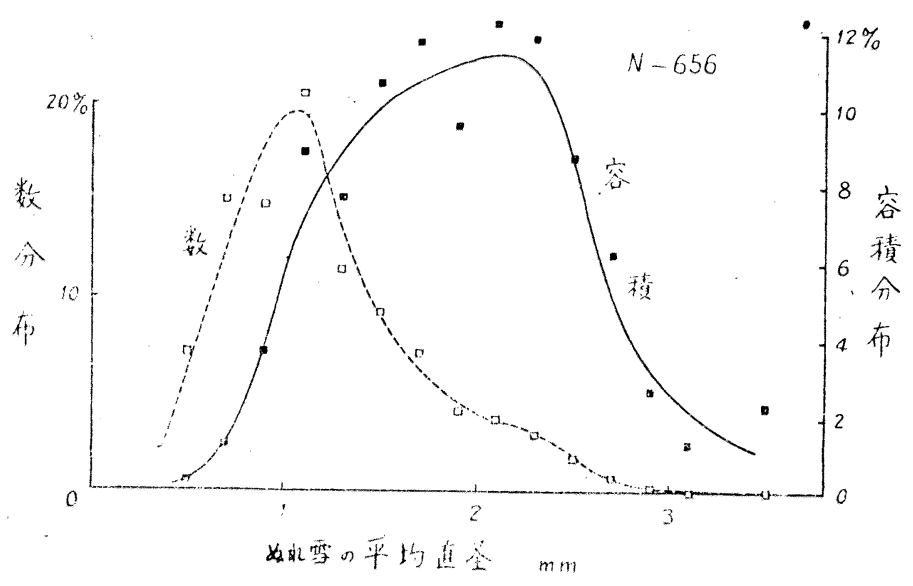

第 6 因

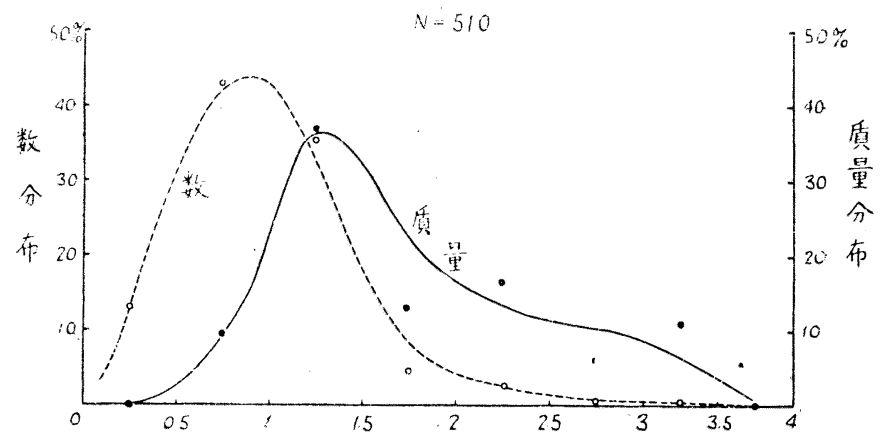

䨋の平坞直圣 $\mathrm{mm}$ 


\section{§ 5. 雨滴と同時に降つた異る降水要素—霬}

雨滴以外の降水要素は痕跡の形 が雨滴に比べてて複雑で兆り，また 融けおくれて残つて含委れている 氷粒のために水がはじくので, 痋 跡にほとばしりを伴うことが多い。 また，融け残つた霖( (ず霞と称 することにずる) が雨滴と同時に 降る場合には，みず霞は印画紙上 での融けかたが抢そいので, 痕跡 も雨滴に比べて濃く変色するので 区別される。念のために著者は融 けてしまわない中に印をつけてお くことにしている。

みず雪の比重は水と殆んぞ変ら ないので，検定法は雨涚になぞら 党る。

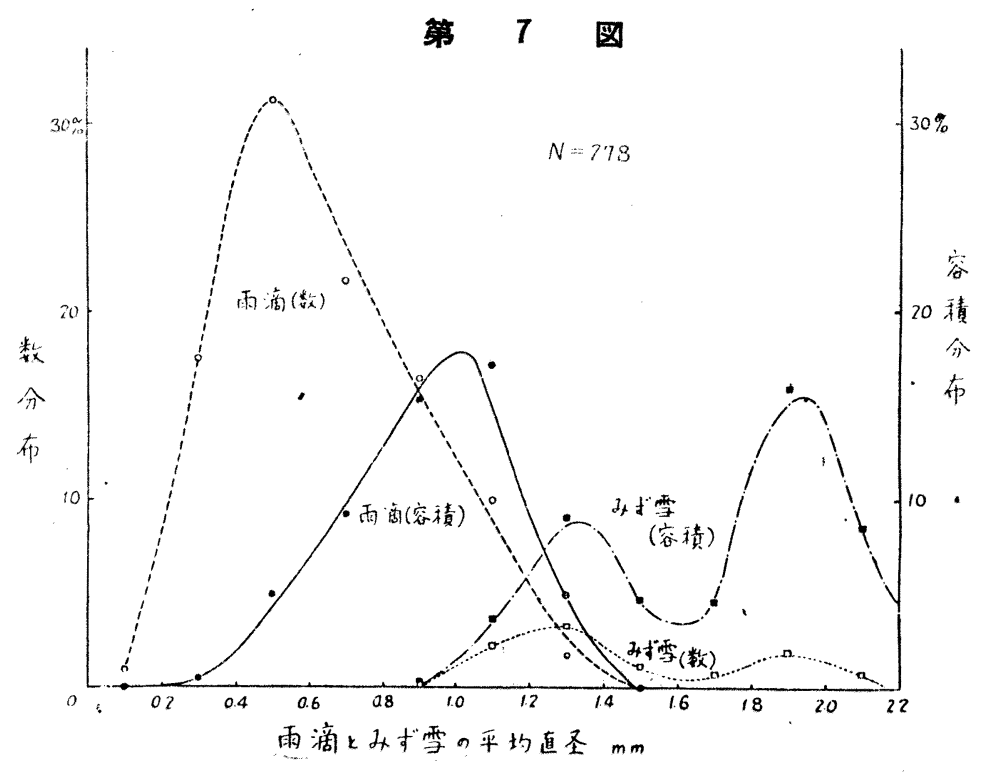

図版 II は同時に降つた2ず雪と雨榈の一例で，その 整理の結果を第 7 図に示す。この場合は容積分布は質 量分布と考光ても差支えないのであるが，みず雪の質量 は雨滴に比べて遥かに大きく，みず雪は融け打くれた雪 片であることが短える。第 8 図 はみず霞の一例である が，印画紙法によつて始めて区別されるもので，雨滴に 比べていくらか大きいようである。

終りに本研究の観測, 整理を手伝つて頂いた荒井・中 山の両氏, 雨滴の検定曲線の作製を蓓当した渡辺・松本 両君に厚く感謝する。点た観測上の便宜を与えられた塩 沢の雪夹験所々長注田氏に深く感謝の意を表す。

本研究は科学研究貿によつて行われたもので女る。
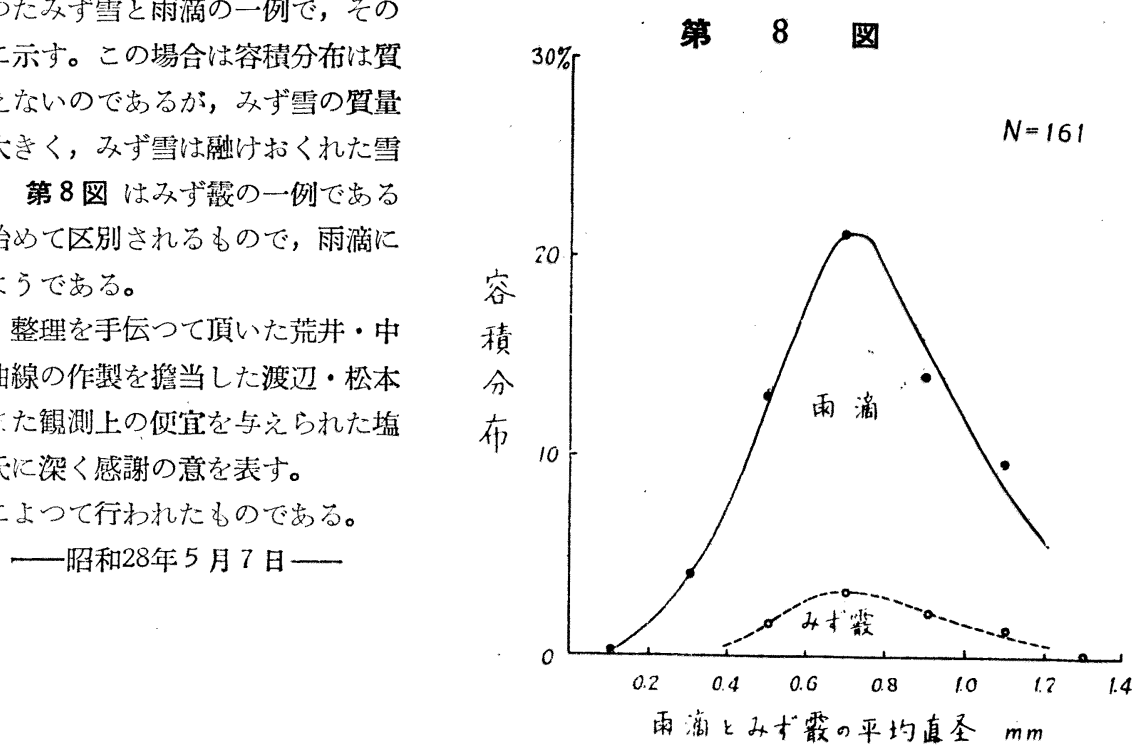

\section{参考女献}

1) V. J. Schaefer ; Snow and its relationship to experimental meteorology : Compendium of Meteorology, P.221 (1951)

2) J. O. Laws ; Measurement of the fall velocity of water drops and raindrops : Transaction of American Geophysical Union , P.709 (1941)

3) 高橋喜彥; 雨觕観測による降雨機棈の研究序報 : 気象集誌, 第 2 輯, 第13巻 67頁 (1935) 